\title{
maandblad voor accountancy en bedrijfshuishoudkunde
}

60e jaargang, $n r .7$ juli/augustus 1986

INHOUDSOPGAVE

Van de redactie blz. 278

Mogelijkheden en beperkingen van expertsystemen blz. 279 door Drs. J. E. M. van Dijk

Informatiebeleid in de knel blz. 295 door Dr. A. H. M. Schrama

De coöperatie: Onderneming, marktgedrag, winstbegrip, aansprakelijkheid, financiering en vermogensstructuur. blz. 307 door Dr. R. Leep

Het $M A B$ vóór 50 jaar.

blz. 322 door A. F. Tempelaar

blz. 324 